Jurnal Bimbingan Konseling
$10(2)(2021): 130-135$
UNNES
https://journal.unnes.ac.id/sju/index.php/jubk

\title{
The Effectiveness of Career Decision Self-Efficacy Group Counseling to Improve Students' Career Adaptability
}

\author{
Angga Yuda Meilanda ${ }^{1 凶}$, Sugiyo Sugiyo ${ }^{2}$, Sunawan Sunawan ${ }^{2}$ \\ ${ }^{1 .}$ Universitas Borneo Tarakan, Kalimantan Utara, Indonesia \\ 2. Universitas Negeri Semarang, Indonesia
}

\begin{tabular}{l}
\hline Article Info \\
\hline History Articles \\
Received: \\
15 Mei 2021 \\
Accepted: \\
16 June 2021 \\
Published: \\
30 August 2021 \\
\hline Keywords: \\
Career adaptability, \\
career decision self- \\
efficacy, group \\
counseling
\end{tabular}

\begin{abstract}
Career adaptability is an individual's readiness which develops over time from the age of children, adolescents, to adults and functions to overcome predictable tasks and participate directly in the work environment and roles. Low adaptability of careers can cause individuals to have difficulty in preparing for their future careers. This study aimed to determine whether career decision self-efficacy (CDSE) group counseling effectively improves students' career adaptability. It was an experimental study that used a randomized pretest-posttest control group design by selecting 18 of 360 students as the subjects of this study and dividing them into 2 groups, namely experimental and control groups. In analyzing the data, this study used Mixed MANOVA. Findings confirmed that career decision self-efficacy group counseling was effective in improving students' career adaptability $(\mathrm{F}(1.16)=$ $1401.74, \mathrm{p}<0.01$. This effectiveness could also be seen in the effect of time ( $\mathrm{F}$ $(2,32)=462.18, \mathrm{p}<0.01)$, and the effect of the interaction between time and group $(\mathrm{F}(2,32)=443.38, \mathrm{p}<0.01)$. Finally, the current study confirms that to improve students' career adaptability, counselors or guidance and counseling teachers can apply CDSE to group counseling services.
\end{abstract}

\footnotetext{
$\bowtie$ Correspondence address:

J1. Wijaya Kusuma I RT. 46 Tarakan, Kalimantan Utara

E-mail: anggayudam@students.unnes.ac.id

p-ISSN 2252-6889

e-ISSN 2502-4450
} 


\section{INTRODUCTION}

The development of today's individual's career is considered significant because an individual can meet the needs of his life and display his talents and interests through a career. One's career can be developed through education as long as all stages of life development (including adolescence) are achieved (Husna et al., 2018). This is confirmed by Ramadani (2020) that the future orientation of young people relates to the developmental tasks they will face in adolescence and early adulthood, such as education, employment, and marriage.

Unfortunately, adolescents who generally sit in high school are still confused about the future of their careers. This is assured by Santrock (Santrock, 2011) who states that many adolescents do not know what career information to look for, and how to find it. Adolescents will not be confused in facing the world of careers if they want to choose and develop according to the desire of their career that is included in the concept of career adaptability.

Career adaptability is currently a very serious problem and receives considerable attention in the development of education, especially in the field of vocational education (Husna et al., 2018). Career adaptability is defined by Savickas $(2012 ;$ 1997) as a psychosocial construct that demonstrates individual resources for coping with career development tasks, work transitions, and personal trauma associated with job roles. An individual who is said to have high career adaptability when he as the ability to overcome career development tasks, transition from education to the world of work, and how he can overcome problems related to his work. Therefore, the world of education, especially vocational education, and the educational institution itself need to be able to develop and optimize career adaptability of their students.

Career adaptability is one of the keys that enable one's competence in a fast-moving and evolving work context. This refers to a set of attitudes, competencies, and behaviors that individuals use in adjusting for work that suits them (Tolentino et al., 2014). Career adaptability has a considerable influence on secondary school students. It is because secondary school students are in the developmental phase of adolescence whose task is to start preparing for a future career (Ginevra et al., 2018).

Career adaptability is part of Savickas's career construction theory (Brown \& Lent, 2013) which explains that a person's process goes through a period of career development, how he works, and his career goals. Career adaptability is a psychosocial construct that shows the source of a person's need to successfully manage and anticipate the current career transition (Savickas, 1997). It is referred to a psychosocial construct because career adaptability resources come from the power of self-regulation derived from a personal individual and an individual's interactions with his environment (M. L. Savickas \& Porfeli, 2012). These powers are used to solve the unfamiliar, complex, and obscure problems that exist in the process of development, job transition, and trauma arising from work. Career adaptability is the readiness to face the tasks of preparing and having a role in the job and adjusting to unexpected changes in a job and working conditions (Edwindha et al., 2017).

On the perspective of individual differences, career adaptability focuses on the adaptability and style of the individual in the situation. From a phenomenological perspective, career adaptability focuses on the subjective goals of self-built adaptation and values when individuals subjectively re-design life stories and strive to be complete and more fully engaged with the world (Karacan-Ozdemir, 2019). To sum up, in the perspective of development, career adaptability focuses on the functions and processes of adaptation throughout the life span and contextual perspectives. It points at historical and cultural situations with their obstacles and capture where individuals must adapt and survive when facing various situations. Career adaptability is essential for 
readiness to face all the demands of preparing and participating in roles in work and the ability to adjust to unexpected changes in working conditions. In addition, career adaptability plays an important role in directing individuals in determining actions and strategies to realize the goals they want to achieve (Savickas, 2012).

Career adaptability is important for students who will later experience the process of transitioning from education to the world of work. It is because during the transition period with unemployment status, an individual will start to understand a sense of competence, examine his career selection and do career planning which later can increase the chances of finding a suitable job for himself (Sahin \& Kirdok, 2018). The positive effect of career adaptability is on results related to an individual's career. Having concern about career allows individuals to imagine their future career possibilities and prepare for them, while having career curiosity allows individuals to explore personal characteristics and job opportunities effectively. Researchers argue that both types of adaptive abilities tend to facilitate the formation of calls to a profession. Unfortunately, this is not in line with what happens in school. Many students have low career adaptability, so they find it difficult to determine their careers after graduation. This will have an impact on the academic satisfaction of students who become severely lacking.

Based on the previous description, the findings of previous studies have not yet explicitly tested how to use career decision selfefficacy (CDSE) as an approach to counseling intervention (Duffy et al., 2015). Then, the purpose of this study was to examine the effectiveness of career decision self-efficacy group counseling to improve the career adaptability of students. The findings of this study are expected to enrich the results of Duffy's study (2015) which found the influence of CDSE on career adaptability. To prove his findings, it is required a study using experimental methods. Therefore, in this study, CDSE was used as an approach for group counseling interventions.

\section{METHODS}

The subjects in this experiment were 18 out of 360 students at SMK Walisongo Semarang. The samples were then divided into two groups, namely experimental group, and control group with each having nine students. This study used a quantitative approach with an experimental research design. The experimental design in this study was in form of a randomized pretest-posttest control group design with repeated measurements. For the sampling technique, it used purposive sampling technique.

Data on student career adaptability were collected using a career adapt-abilities scale developed by Savickas and Porfeli (2012) consisting of 24 items from 4 career adaptability constructs (concern, control, curiosity, confidence). Career adaptability scale assessment was done using a Likert scale form with five answer options ( $1=$ strongly disagree until $5=$ agree). In terms of reliability test, the scale gained a Cronbach's alpha coefficient of 0.94 .

In the first procedure, the researchers gave a pretest to determine the adaptability of the student's career before the intervention. Second, the counseling interventions using career decision self-efficacy approach that adopted the intervention procedures developed by Betz (Betz, 1992; Sullivan \& Mahalik, 2000) were given for five times with an allocation of 60 minutes for each session. The purpose of the five sessions was to learn about career decision making as a process, group exercises (for example, having group members share stories about how parental models have influenced their career development), and off-group tasks for group members (for example, interviewing someone they might consider having been successful in their career decision-making process). Third, the researchers gave post-test to see changes in the subject's career adaptability. Fourth, the researchers conducted follow-up activities for two weeks after the post-test. Then, the data collected from pre-test, post-test, and follow-up were analyzed using Mixed 
MANOVA to see the improve in students career adaptability.

\section{RESULTS AND DISCUSSION}

The descriptive statistical results from this study showed that there was a significant increase in mean and standard deviation in the experimental group, namely pre-test $(\mathrm{M}=61.89$, $\mathrm{SD}=1.36)$ experienced a significant increase in post-test $(\mathrm{M}=87.22, \mathrm{SD}=2.22)$, and follow-up $(\mathrm{M}=88.89, \mathrm{SD}=1.83)$. The increase could be said to exceed the results of the control group, namely pre-test $(\mathrm{M}=61.44, \mathrm{SD}=1.23)$ did not experience significant changes in post-test $(\mathrm{M}=$ $61.78, \mathrm{SD}=1.39)$, and follow-up $(\mathrm{M}=61.67$, $\mathrm{SD}=1.22$ ). Further results of the analysis can be seen in table 1 .

Table 1. Descriptive Statistical Analysis Results

\begin{tabular}{llll}
\hline & & Experiment & Control \\
\hline Pre-test & $\mathrm{M}$ & 61.89 & 61.44 \\
& $\mathrm{SD}$ & 1.36 & 1.23 \\
Post-test & $\mathrm{M}$ & 87.22 & 61.78 \\
& $\mathrm{SD}$ & 2.22 & 1.39 \\
Follow- & $\mathrm{M}$ & 88.89 & 61.67 \\
up & $\mathrm{SD}$ & 1.83 & 1.22 \\
\hline
\end{tabular}

Mixed MANOVA analysis in table 2 shows the effect of time on the increase in career adaptability level $(\mathrm{F}(2.32)=462.18, p<0.01)$, group effect $(\mathrm{F}(1,16)=1401.74, p<0.01)$, and effect of time and group interaction $(\mathrm{F}(2.32)=$ 443.38, $p<0.01)$. The increase in students' career adaptability level in the experimental group indicated that time, group, and the interaction between time and group contributed positively effects. In details, the increase can be seen in figure 1.

Table 2. Mixed MANOVA Analysis Results

\begin{tabular}{llll}
\hline Efek & F & df & $p$ \\
\hline Waktu & 462.18 & 2,32 & $<0.01$ \\
Kelompok & 1401.74 & 1,16 & $<0.01$ \\
Waktu*Kelompok & 443.38 & 2,32 & $<0.01$ \\
\hline
\end{tabular}

Table 3. Pairwise Comparisons Results

\begin{tabular}{llll}
\hline Waktu & MD & SE & $p$ \\
\hline T1-T2 & -12.833 & 0.527 & $<0.01$ \\
T1-T3 & -13.611 & 0.519 & $<0.01$ \\
T2-T3 & -0.778 & 0.460 & $<0.01$ \\
\hline
\end{tabular}

Based on table 3, there found an improvement based on the results of a comparison between the effects of time and career adaptability (T1-T2), (T1-T3). In other words, there was an improvement in student's career adaptability that occurred in each phase of measurement. Based on the data described above, the use of career decision self-efficacy group counseling proved effective in improving the career adaptability of the experimental group. In the experimental group, pre-tests to post-tests showed increases in score. The same thing also happened after the follow-up phase. It can be said that the experimental group improved from low to high levels. In contrast, the control group did not experience any improvement in career adaptability. This was evidenced by the stable condition in the pre-test, post-test, and follow-up results which remained low.

Interestingly, the results of this study also revealed and confirmed that the intervention of career self-efficacy approach was effective to improve career adaptability. This is in line with a study by (Autin et al., 2017; Buyukgoze-Kavas et al., 2015; Duffy et al., 2015; Jadidian \& Duffy, 2012) in which four components (concern, control, curiosity, and confidence) of career adaptability have a strong relationship with career self-efficacy. When a student feels confident in determining their career, he can be said to have excellent career adaptability as well. Good career adaptability will be a perfect bridge to future success and enable to compete with other individuals. In addition, career adaptability plays an essential role in directing individuals in determining actions and strategies to realize the goals they want to achieve (Savickas, 2012).

The findings of this study are in line with a previous study that proves that a counseling intervention (psychoeducational group) can improve career adaptability (Pambudi et al., 
2019). Furthermore, it fosters a sense of career expectations that have been possessed and forms a condition of good career adaptability so that in the end individuals can adapt to their lives. In the implementation of interventions made in this study, the counselor tried to make the counselees accept their weaknesses and realize that they have strengths to develop their potential. More importantly, counselors or guidance and counseling teachers need to realize the importance of helping students to improve student's career adaptability by providing career decision self-efficacy group counseling services. Teachers also need to work with students to carry out this counseling to get optimal results.

\section{CONCLUSION}

Regarding the findings, this study concludes that the career adaptability of students improves after the implementation career decision self-efficacy group counseling in the experimental group. Using CDSE in group counseling, interventions will strengthen the career adaptability of students. With stronger beliefs and the ability to understand the potential to plan a career, students will be easier to carry out learning tasks and improve academic achievement to determine and choose future career opportunities that suit their interests and potentials.

Apart from its findings, this study still has limitations. The subjects in this study have different gender so that the future studies are recommended to examine one gender only to have the possibility getting different results. In addition, the study provided a follow-up of the subject for two weeks. Therefore, the future researchers are expected to offer a month-long follow-up to see how significant the effect of the intervention is.

\section{REFRENCES}

Autin, K. L., Douglass, R. P., Duffy, R. D., England, J. W., \& Allan, B. A. (2017). Subjective social status, work volition, and career adaptability: A longitudinal study. Journal of Vocational Behavior, 99, 110.

https://doi.org/10.1016/j.jvb.2016.11.00 7

Betz, N. E. (1992). Counseling uses of career self-efficacy theory. The Career Development Quarterly, 41(1), 22-26. https://doi.org/10.1002/j.21610045.1992.tb00352.x

Brown, S. D., \& Lent, R. W. (2013). Career development and counseling: putting theory and research to work. In John Wiley \& Sons (Vol. 53, Issue 9). https://doi.org/10.1017/CBO978110741 5324.004

Buyukgoze-Kavas, A., Duffy, R. D., \& Douglass, R. P. (2015). Exploring links between career adaptability, work volition, and well-being among Turkish students. Journal of Vocational Behavior, 90, 122-131.

https://doi.org/10.1016/j.jvb.2015.08.00 6

Duffy, R. D., Douglass, R. P., \& Autin, K. L. (2015). Career adaptability and academic satisfaction: Examining work volition and self efficacy as mediators. Journal of Vocational Behavior, 90, 46-54. https://doi.org/10.1016/j.jvb.2015.07.00 7

Edwindha, P. N., Wibowo, M. E., \& Murtadho, A. (2017). Hubungan kecerdasan emosional dengan prestasi belajar: analisis mediasi adaptabilitas karir pada prestasi belajar. Jurnal Bimbingan Konseling, $\quad 6(2), \quad 127-134$. http://journal.unnes.ac.id/sju/index.php /jubk

Ginevra, M. C., Magnano, P., Lodi, E., Annovazzi, C., Camussi, E., Patrizi, P., \& Nota, L. (2018). The role of career adaptability and courage on life satisfaction in adolescence. Journal of Adolescence, 62(May 2017), 1-8. https://doi.org/10.1016/j.adolescence.20 17.11.002

Husna, H. A., Dwi, M., \& Santia, R. (2018). Perbedaan adaptabilitas karir pada 
peserta didik di Pondok Pesantren Darussalan dan SMK Negeri 1 Martapura. Jurnal Kognisia, 1(1), 29-37.

Jadidian, A., \& Duffy, R. D. (2012). Work volition, career decision self-efficacy, and academic satisfaction: An examination of mediators and moderators. Journal of Career Assessment, 20(2), 154-165. https://doi.org/10.1177/1069072711420 851

Karacan-Ozdemir, N. (2019). Associations between career adaptability and career decision-making difficulties among Turkish high school students. International Journal for Educational and Vocational Guidance, $\quad$ 19(3), 475-495. https://doi.org/10.1007/s10775-01909389-0

Pambudi, A. T., Mulawarman, \& Japar, M. (2019). Psychoeducational group with modelling technique to improve career adaptability through career decision selfefficacy aji. Jurnal Bimbingan Konseling, 8(1), 20-31.

Ramadani, D., Fachrurrazi, M., \& Hidayat, D. R. (2020). Adaptabilitas karir dalam perspektif teori perkembangan karir mark 1. Savickas. Jurnal Jurusan Bimbingan Konseling Undiksha, 11(1).

Sahin, I., \& Kirdok, O. (2018). Investigation of relationship between high school students' career adaptability, subjective well-being, and perceived social support. International Education Studies, 11(8), 127. https://doi.org/10.5539/ies.v11n8p127

Santrock, J. W. (2011). Masa perkembangan anak. Jakarta: Salemba Humanika.
Savickas, M. (2012). Life design: A paradigm for career intervention in the 21 st century. Journal of Counseling and Development, 90(1), 13-19. https://doi.org/10.1111/j.15566676.2012.00002.x

Savickas, M. L. (1997). Career adaptability: an integrative construct for lifespan, lifespace theory. In The Career Development Quarterly (Vol. 45, Issue 3, pp. 247-259). https://doi.org/10.1002/j.21610045.1997.tb00469.x

Savickas, M. L., \& Porfeli, E. J. (2012). Careers adapt-abilities scale: construction, reliability, and measurement equivalence across 13 countries. Journal of Vocational Behavior, 80(3), 661-673. https://doi.org/10.1016/j.jvb.2012.01.01 1

Sullivan, K. R., \& Mahalik, J. R. (2000). Increasing career self-efficacy for women: Evaluating a group intervention. In Journal of Counseling and Development (Vol. 78, Issue 1, pp. 54-62). https://doi.org/10.1002/j.15566676.2000.tb02560.x

Tolentino, L. R., Garcia, P. R. J. M., Lu, V. N., Restubog, S. L. D., Bordia, P., \& Plewa, C. (2014). Career adaptation: The relation of adaptability to goal orientation, proactive personality, and career optimism. Journal of Vocational Behavior, 84(1), 39-48. https://doi.org/10.1016/j.jvb.2013.11.00 4 